\title{
Developing the Molecular Genetic Component of Microbiological Monitoring of Nosocomial Acute Enteric Viral Intections
}

DOI: 10.17691/stm2017.9.3.15

Received January 26, 2017

V.V. Shkarin, MD, DSc, Corresponding Member of the Russian Academy of Sciences, Consulting Professor,

Department of Epidemiology?

A.v. Sergeeva, MD, PhD, Associate Professor, Department of Epidemiology,

Head of the Problem Research Laboratory of PCR Studies, Scientific Research Institute of Preventive Medicine';

L.X. Poslova, MD, PhD, Head of Epidemiological Department2;

O.V. Kovalishena, MD, DSc, Interim Head of the Department of Epidemiology; Deputy Director of Research,

Scientifie Research Institute of Preventive Medicine';

A.S. Blagonravova, MD, DSc, Professor, Department of Epidemiology,

Director of the Scientific Research Institute of Preventive Medicine';

N.V. Epifanova, PhD, Leading Researcher, Laboratory of Molecular Epidemiology of Viral Infections;

T.A. Sashina, Junior Researcher, Laboratory of Molecular Epidemiology of Viral Infections ${ }^{3}$;

O.V. Morozova, Junior Researcher, Laboratory of Molecular Epidemiology of Viral Infections;

N.A. Novikova, DSc, Professor, Head of the Laboratory of Molecular Epidemiology of Viral Infections ${ }^{3}$

'Nizhny Novgorod State Medical Academy, 10/1 Minin and Pozharsky Square, Nizhny Novgorod, 603005,

Russian Federation;

${ }^{2}$ Nizhny Novgorod Regional Children's Hospital, 211 Vaneeva St., Nizhny Novgorod, 603136,

Russian Federation;

${ }^{3}$ Nizhny Novgorod Scientific Research Institute of Epidemiology and Microbiology

named after Academician Blokhina, 71 Malaya Yamskaya St., Nizhny Novgorod, 603950, Russian Federation

The aim of the investigation was improving the effectiveness of microbiological monitoring through optimization and development of the molecular genetic component based on comprehensive long-term assessment of hospital-acquired acute enteric infections of viral etiology.

Materials and Methods. In the framework of epidemiological surveillance of nosocomial viral infections, syndrome-based diagnosis of acute enteric infection cases was implemented in a children's hospital. In fact, the patients with the signs of gastrointestinal dysfunctions unrelated to the underlying disease were identified and examined. DNAs (RNAs) of acute enteric infections of viral etiology were detected and differentiated through PCR-based diagnosis. G[P]-typing of rotaviruses was performed by RT-PCR method using various primers. Genotyping of enteric viruses by sequencing method was performed determining the relevant nucleotide sequences of rotavirus, norovirus and astrovirus cDNA segments using genetic analyzer Beckman Coulter. Nucleotide sequences of cDNA segments were analyzed using BLAST programs to identify closely related strains and an online service for automatic genotyping of noroviruses. Alignment of nucleotide sequences and phylogenetic analysis were performed using MEGA software. Sequences of genome segments obtained in this study have been represented in the international GenBank database.

Results. There has been developed the molecular genetic component of microbiological monitoring of acute enteric infections of viral etiology, which involves not only diagnosing the enteric pathogens by PCR, but also subsequent genotyping as well as phylogenetic analysis to determine genetic characteristics of pathogens.

Key words: epidemiological surveillance; nosocomial infections; acute enteric infections of viral etiology; microbiological monitoring; norovirus; rotavirus; adenovirus; astrovirus.

Studying different aspects of the problem of acute enteric infections (AEI) of viral etiology is urgent today due to their wide spread, polyetiology, variety of transmission ways and factors, marked seasonality, the continuing upward trend in incidence often acquiring group character and occurring as outbreaks, particularly among pediatric population [1-6]. The outbreaks of viral AEI can be also registered in various healthcare institutions specializing in both infectious and noninfectious diseases $[1,3,7,8]$. This situation requires effective epidemiological investigation to assess the relationship of various diseases, identify the sources of

For contacts: Angelica V. Sergeeva, e-mail: sergeeva-av2013@yandex.ru 
pathogens, transmission routes and, most importantly, establish the presence or absence of healthcareassociated infections (HAls).

The Russian system of epidemiological surveillance for acute enteric infections of viral etiology allows assessing the epidemiological situation, planning, correcting and providing scientific grounds for control measures. This system is an open and evolving structure that provides the possibility to introduce new parameters and components, thereby improving it. This is especially relevant in connection with the development of molecular-genetic research methods.

The existing molecular biological component of microbiological monitoring of viral AEI does not fully disclose the use of different types of genotyping and phylogenetic analysis to determine genetic characteristics of pathogens and therefore does not provide identification of conditions in which infections occur in medical settings.

The aim of the investigation was improving the effectiveness of microbiological monitoring through optimization and development of the molecular genetic component based on comprehensive long-term assessment of hospital-acquired acute enteric infections of viral etiology.

Materials and Methods. The research was carried out on the basis of a multidisciplinary clinic, Nizhny Novgorod Regional Children's Hospital. At the first stage of work, syndrome-based diagnosis of AEl cases was implemented in this non-infectious hospital as part of epidemiological surveillance for nosocomial viral infections according to the developed algorithm which involved identification and screening of patients with the signs of gastrointestinal dysfunctions unrelated to the underlying disease for a wide range of pathogens. Besides, the persons who stayed in contact with the patients having the specified syndrome or a confirmed $\mathrm{AEI}$ diagnosis were examined as well. Microbiological monitoring was carried out by examination of swabs from environmental objects of hospital departments with AEl cases.

On the basis of the Problem Research Laboratory of PCR studies, the Scientific Research Institute of Preventive Medicine of Nizhny Novgorod State Medical Academy, real-time PCR method was applied to carry out differential detection of group A rotavirus, noroviruses, astroviruses, enteroviruses and group $F$ adenoviruses, their DNA (RNA) analyzed, using AmpliSens ${ }^{\circledR}$ AEl screen-FL kit (Central Scientific Research Institute of Epidemiology and Microbiology, Moscow). A total of 178 samples of feces and 23 swabs from the hospital environment were studied during the period of 2013-2014. There were made 1,038 studies.

The study complies with the Declaration of Helsinki (the Declaration was passed in June 1964, Helsinki, Finland, and revised in October 2000, Edinburgh, Scotland) and was performed following approval by the ethic committee of Nizhny Novgorod State Medical
Academy. Written informed consent was obtained from the parents of the patients.

At the second stage of work, genotyping of $132 \mathrm{AEI}$ pathogens was carried out. The study was performed at the Laboratory of Molecular Epidemiology of Viral Infections, Nizhny Novgorod Scientific Research Institute of Epidemiology and Microbiology named after Academician Blokhina (Nizhny Novgorod). G[P]-typing of rotaviruses was performed by RT-PCR method using primers identifying types G1, G2, G3, G4, G9 and P[4], $P[6], P[8], P[9]$ [9]. Genotyping of enteric viruses by sequencing method was performed determining the relevant nucleotide sequences of rotavirus, norovirus and astrovirus cDNA segments using genetic analyzer Beckman Coulter (Beckman Coulter, USA) [10-13]. Nucleotide sequences were analyzed using BLAST programs to identify closely related strains and online service Norovirus Genotyping Tool Version 1.0. for automatic genotyping of noroviruses. Alignment of nucleotide sequences and phylogenetic analysis were performed using MEGA software. Sequences of genome segments obtained in this study have been represented in the international GenBank database.

At the third stage of work, phylogenetic analysis was performed based on the aligned nucleotide sequences using MEGA software. Nucleotide sequences of enteric virus genome available in the international GenBank database (USA) were used for comparison. Phylograms were built by neighbor-joining method based on Kimura two-parameter model. The accuracy of phylogram topology was assessed by bootstrap analysis using 1,000 random samples. Genome fragment sequences obtained in this study have been represented in the international GenBank database under numbers KP208780, KP208781 (astroviruses), KP208782KP208785, KR020053 (noroviruses), KR020054 (rotaviruses). The results were statistically processed according to the standard technique by methods of variation statistics [14].

The final stage involved epidemiological assessment of epidemical situation in the children's multidisciplinary hospital on the basis of investigation data of infection cases, microbiological monitoring including molecular genetic studies and comparison of the obtained results with epidemiological surveillance data of viral $A E I$ in the region.

Results and Discussion. At the first stage of the study, it was found that enteric viruses were detected in $43.8 \%$ of patients with the syndrome of gastrointestinal dysfunction unrelated to the underlying disease $(95 \%$ Cl 40.1-47.5) [4]. Among the persons infected with enteric viruses, mono-infection was diagnosed in $72 \%$ of patients, mixed infection in $28 \%(p=0.007)$. Rotavirus and norovirus infections $(92.1 \%)$ dominated in viral associations. Thus, in children's clinical hospital, viral $\mathrm{AEI}$ was found in almost every second child with the signs of gastrointestinal dysfunction unrelated to the underlying disease. 


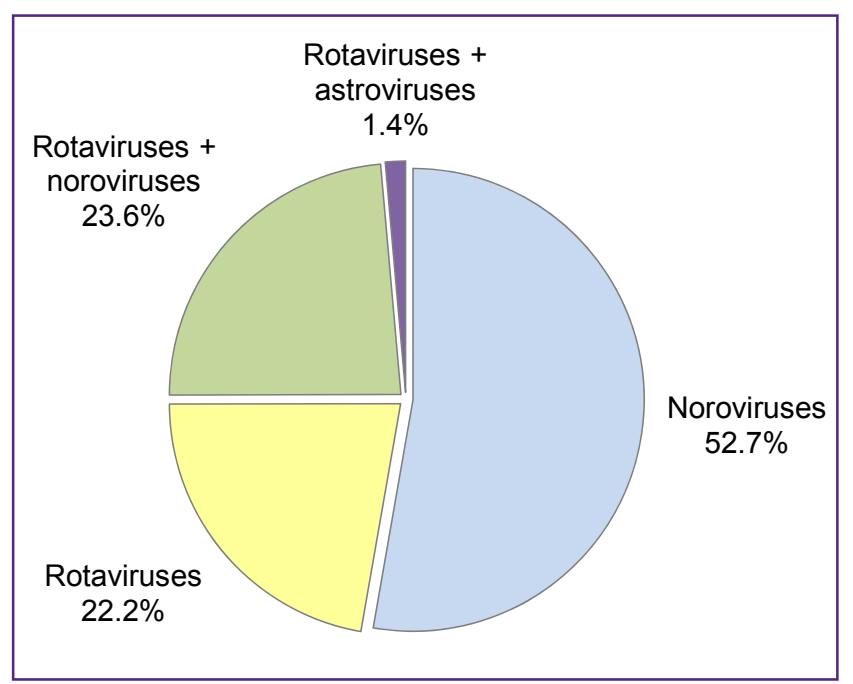

Figure 1. Etiological structure of acute enteric viral infections in patients of non-infectious children's multidisciplinary hospital
When analyzing $\mathrm{AEI}$ in terms of etiology, it was found in 2013 that norovirus infection prevailed in $73.2 \%$ (95\% $\mathrm{Cl}, 69.9-76.5)$ of patients with mono-infection $(p=0.045)$. Rotavirus infection came second and accounted for $23.2 \%(95 \% \mathrm{Cl} 20.0-26.4)$. The proportions of astrovirus and adenovirus infections were $1.8 \%(95 \% \mathrm{Cl} 0.9-2.7)$ of cases each (Figure 1).

To reveal the extent of clinic premises contamination by intestinal viruses, canteen objects, wards for patients, medical station, restrooms and toilets in one of the hospital departments were examined. The swabs from light switches, door handles, surfaces of dining tables, bedside tables, and beds were collected. Enteric viruses were found in $47.8 \%(95 \% \mathrm{Cl} 37.4-58.2)$ of swabs: $39.1 \%$ of swabs were sampled in the hospital wards and $8.7 \%$ in toilets. In $39.1 \%$ of samples $(95 \% \mathrm{Cl} 24.4-$ 53.8) the presence of monoinfection was revealed: noroviruses accounted for $26.1 \%$, and rotaviruses for $13.0 \%$. Given the stability of enteric viruses in the environment, it is obvious that contaminated objects

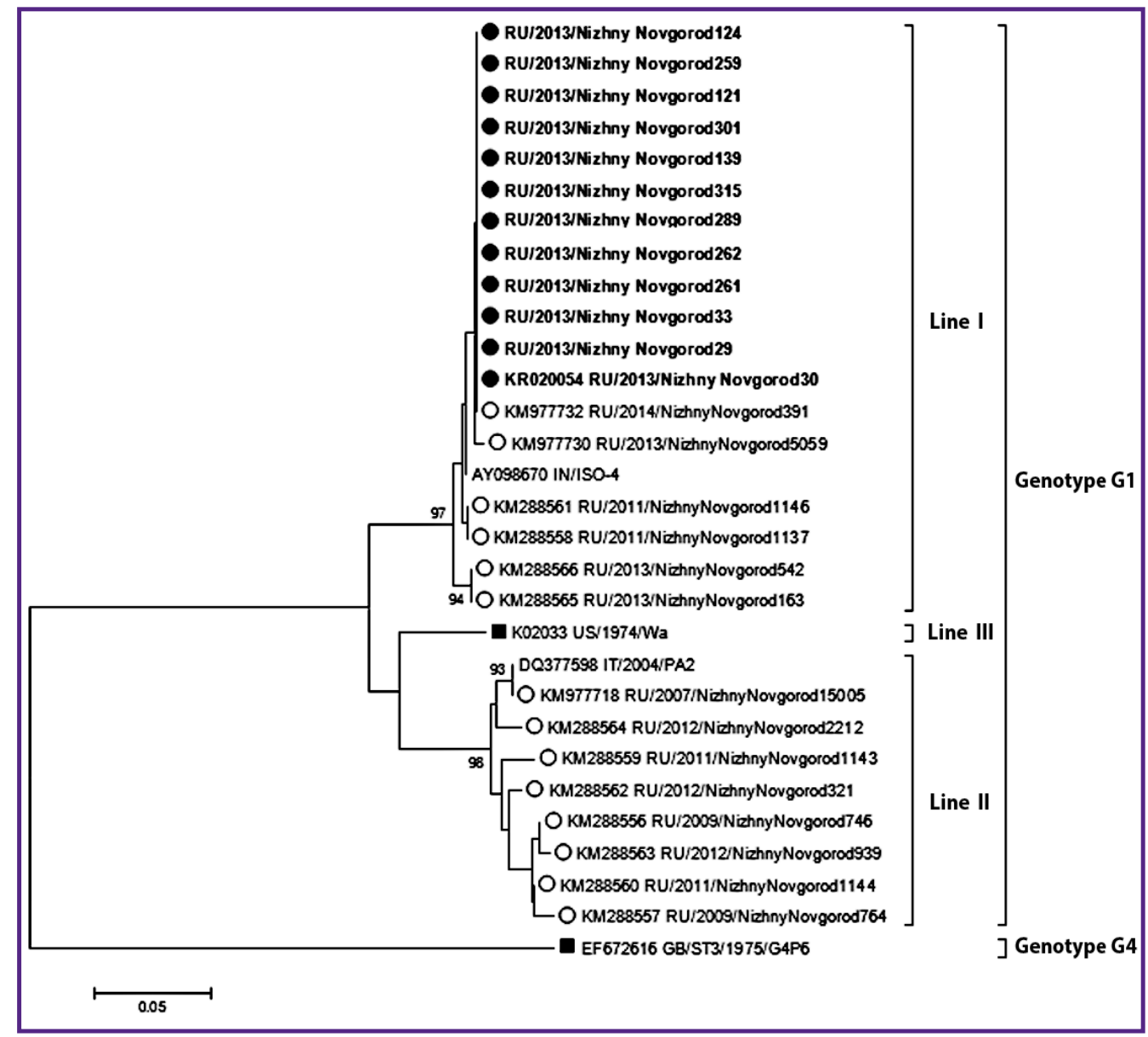

Figure 2. The phylogenetic tree constructed on the basis of nucleotide sequence analysis of VP7 gene segment of rotavirus genome:

- - Isolates detected in this study;

- - Isolates detected in other studies on the territory of Nizhny Novgorod;

- - Standard reference rotavirus strains of genotypes G1 and G4;

Names of countries are indicated using two-letter code ISO-3166-1 
are likely to be a permanent factor of $A E I$ transmission in the hospital. This fact requires improvement of preventive and epidemic control measures, as well as implementation of environmental monitoring of hospital environment for contamination with viruses.

The next stage of work was devoted to phylogenetic analysis of the established nucleotide sequences of enteric virus genome segments.

Genotyping of rotaviruses by RT-PCR and sequencing revealed the presence of genotypes G4P[8] in 30.0\% and G1P[8] in $70.0 \%$ of cases. While conducting this research on the territory of Nizhny Novgorod, rotaviruses A belonging to five $G$ types ( $G 1, G 2, G 3, G 4, G 9)$ and four P-types (P[4], $P[6]$, $P[8] P[9])$ were identified. $\mathrm{G} 4 \mathrm{P}[8]$ was the predominant genotype and accounted for $40.3 \%$. The data on circulation of enteric viruses on the territory of Nizhny Novgorod suggest that registering the cases of rotavirus G4P[8] genotype in patients was due to repeated bringing the infection to the hospital.

Rotavirus G1P[8] genotype was detected in 70\% of hospital patients. Phylogenetic analysis showed contamination with one rotavirus variant related to line G1-I. Homology was 99.9-100\% (Figure 2). On the territory of Nizhny Novgorod, it was detected in $12.1 \%$ of cases [15], but representatives of line G1-II were mainly in circulation. The results obtained in our study speak of stable circulation of rotavirus G1-I genotype in intrahospital conditions.

Thus, according to the epidemiological investigation of infection cases, studying the genetic characteristics of

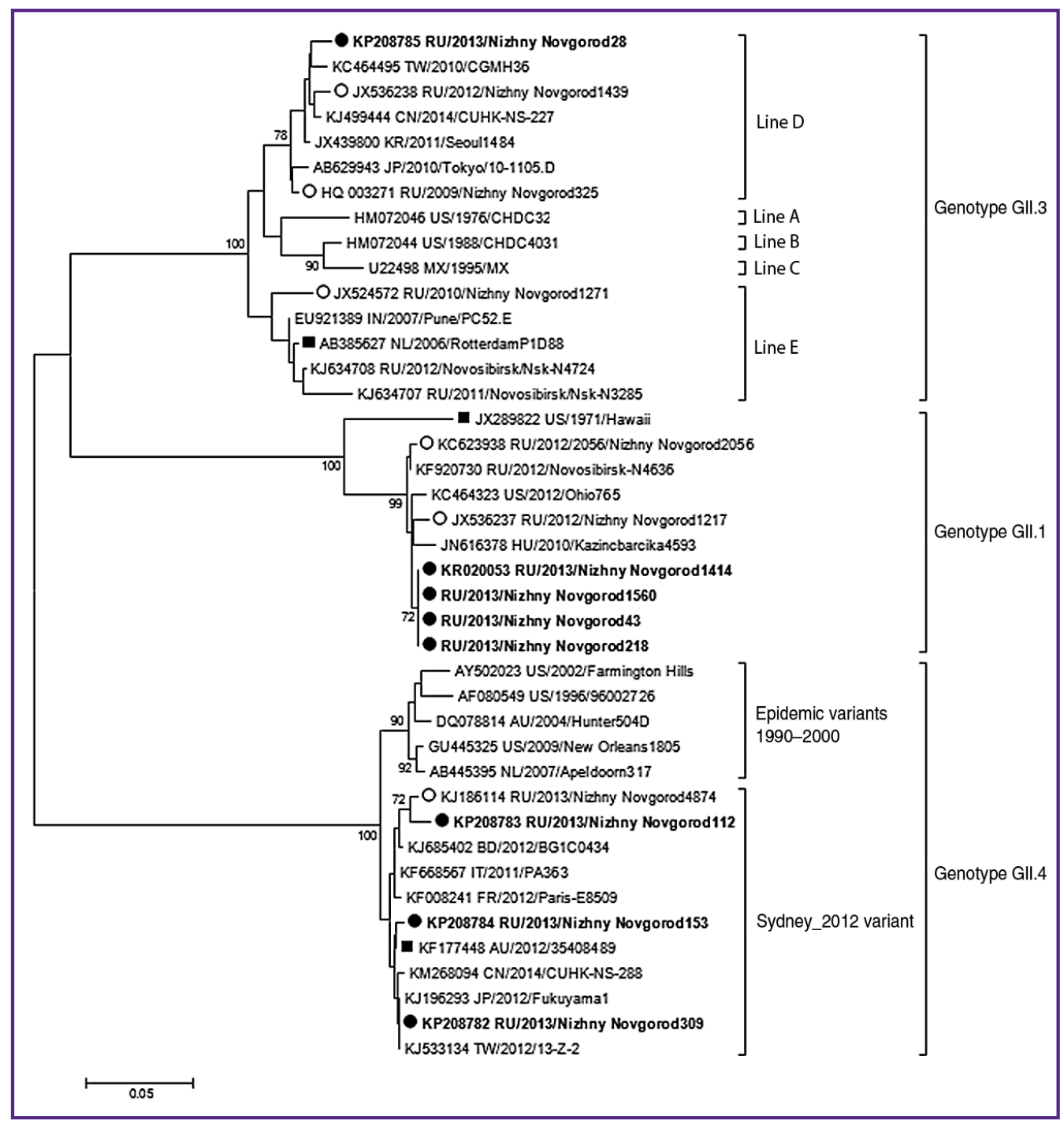

Figure 3. The phylogenetic tree constructed on the basis of nucleotide sequence analysis of VP1 gene segment of norovirus genome:

- - Isolates detected in this study;

- - Isolates detected in other studies on the territory of Nizhny Novgorod;

- - Standard reference norovirus strains of various genotypes GII.1, GII.3, GII.4;

Names of countries are indicated using two-letter code ISO-3166-1 
pathogens and comparing to the information about the enteric viruses circulating in the city, it was established that in hospital patients with rotavirus infections, 6 cases could be classified as bringing the infection and 14 cases were attributed to HAls.

Genotyping of noroviruses revealed high prevalence of GIl genogroup. Norovirus GII.1 and GII.4 genotypes accounted for $44.4 \%(95 \% \mathrm{Cl} 27.8-61.0)$ and Gll.3 $11.1 \%$. The detected noroviruses GII.1 genotype were identical to each other in the studied genome segment and similar to the only isolate of this norovirus genotype identified during the period 2006 to 2012, with the incidence being sporadic in Nizhny Novgorod, and similar to the norovirus which caused $A E I$ outbreak in one of the city's educational establishments in September 2012 (homology - 99.9\%) [5]. AEI cases identified in this study were caused by hospital-acquired norovirus infection after the pathogen circulating on the territory was brought to the hospital.

Noroviruses Gll.4 belonged to Sydney_2012 genovariant which was first detected in Australia in March 2012 and in 2012-2013 gained epidemic spread worldwide [16]. Although isolates of Gll.4 Sydney 2012 identified in this work belonged to the same genovariant, they differed significantly from each other in the studied genome segment (divergence was 0.7-2.4\%) and were assigned to separate clusters during phylogenetic analysis of nucleotide sequences (Figure 3 ).

In this connection, the analyzed cases are likely to be the result of independent bringing of norovirus GIl.4 to the medical organization. Although more research is needed, we cannot completely exclude that the observed divergence is the result of circulation in the confined space of the hospital.

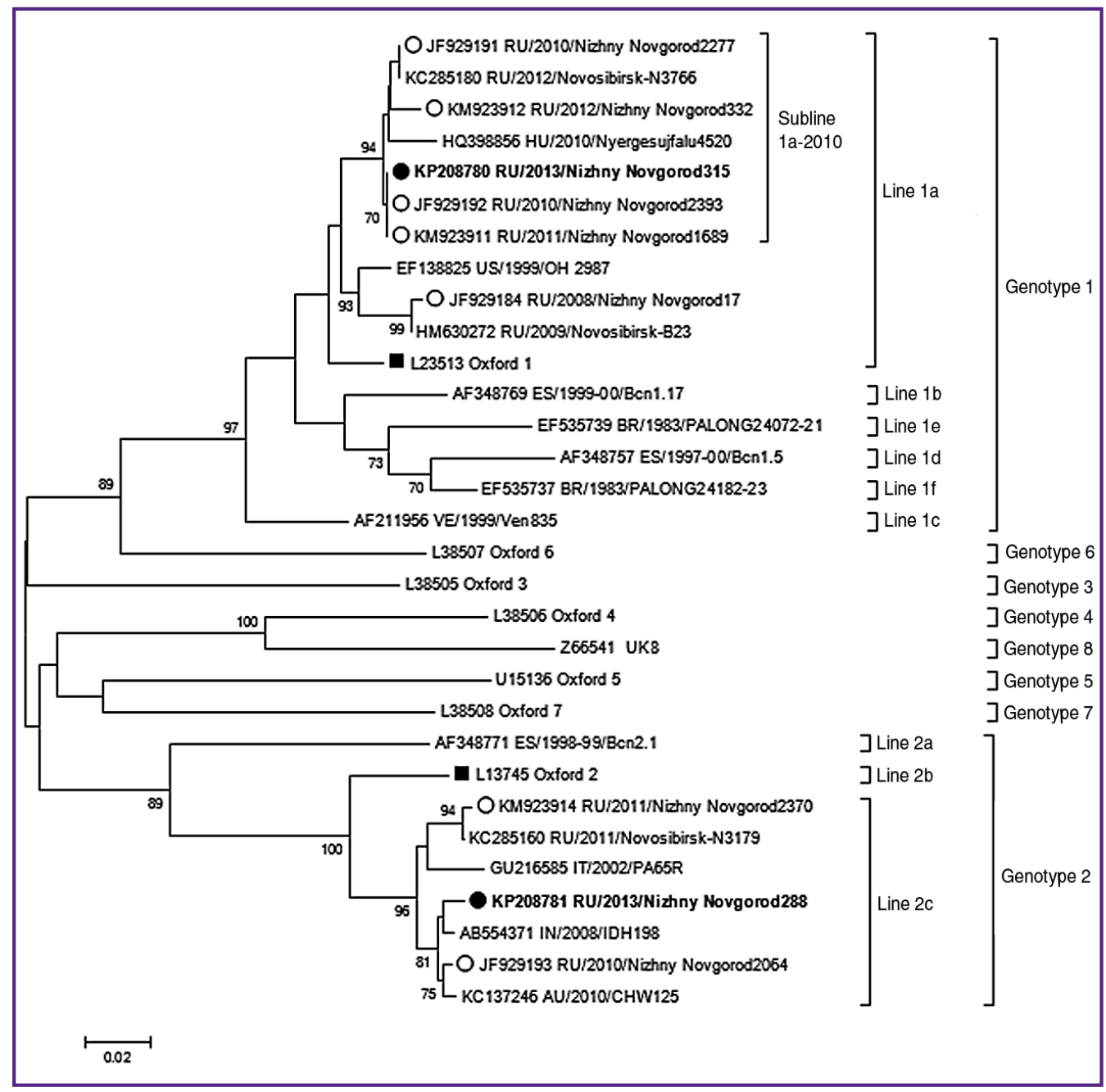

Figure 4. The phylogenetic tree constructed on the basis of nucleotide sequence analysis of the gene precursor to capsid proteins of astrovirus genome:

- - Isolates detected in this study;

o - Isolates detected in other studies on the territory of Nizhny Novgorod;

- - Standard reference astrovirus strains of genotypes 1 and 2;

Names of countries are indicated using two-letter code ISO-3166-1 
Phylogenetic analysis revealed that norovirus Gll.3 sequence belonged to line $D$ according to the classification of Mahar et al. [17].

When genotyping astroviruses, one isolate was found to belong to genotype 1 , line $1 \mathrm{~A}$, subline $1 \mathrm{~A}-2010$. This genotype is the most common and has a high level of genetic heterogeneity [6, 15]. Another isolate belongs to astrovirus of genotype 2 , genetic line $2 \mathrm{C}$ which is characterized by low circulation in the world $[6,18]$ (Figure 4).

Belonging of astroviruses detected in two episodes of hospital infection to different genotypes in combination with epidemiological investigation data makes it possible to classify them as cases of independent bringing to the hospital.

Results obtained in this study provided the basis for improving the components of epidemiological surveillance system for enteric infections of viral etiology in Russia, particularly, epidemiological monitoring. Given the introduction of new molecular genetic technologies along with scientific research implementation, special attention was paid to improving the microbiological component of epidemiological surveillance for $\mathrm{AEI}$ (Figure 5).

Epidemiological monitoring intended for epidemiological diagnosis of viral AEI in the children's multidisciplinary non-infectious hospital, in our opinion, should include the following components:

1) syndrome-based diagnosis providing identification and screening of patients with the signs of gastrointestinal dysfunctions unrelated to the underlying disease as well as contact persons (other patients, responsible informants, medical personnel) according to the developed algorithm;

2) assessment of viral AEI incidence and prevalence, particularly, in the context of etiology;

3) epidemiological examination of $\mathrm{AEI}$ cases in the hospital setting analyzing infection occurrence conditions (bringing infections or HAls), the causes and factors contributing to AEI emergence and spread, as well as the ways and factors of transmission, contact persons;

4) investigation of epidemiological situation (group disease and outbreaks);

5) interpretation of microbiological monitoring results, including molecular biological component, specification of infection occurrence conditions (bringing infections or HAls), the ways and factors of causative agent transmission, characteristics of pathogen circulation in the medical organization;

6) comparison of epidemiological diagnosis results with epidemiological surveillance data on the territory;

\begin{tabular}{|c|c|c|}
\hline Epidemiological monitoring & \multicolumn{2}{|c|}{$\begin{array}{l}\text { Molecular genetic component } \\
\text { of microbiological monitoring }\end{array}$} \\
\hline & Patients & Environment \\
\hline $\begin{array}{l}\text { Syndrome-based diagnosis: identification } \\
\text { and screening of patients with the signs } \\
\text { of gastrointestinal dysfunctions unrelated } \\
\text { to the underlying disease and contact persons } \\
\text { according to the developed algorithm } \\
\text { Evaluation of incidence and prevalence } \\
\text { of viral AEI, particularly, in etiological context } \\
\text { Epidemiological examination of AEI cases, } \\
\text { differentiation of bringing infections and HAls, } \\
\text { the causes, ways, and factors of transmission, } \\
\text { identification of contact persons } \\
\text { Investigation of epidemiological situation } \\
\text { (group disease and outbreaks) } \\
\text { Interpretation of microbiological monitoring } \\
\text { results, including molecular biological } \\
\text { component, differentiation of bringing infection } \\
\text { and HAls, the causes, ways, and factors } \\
\text { of virus transmission and circulation } \\
\text { in the hospital } \\
\text { Comparison of epidemiological diagnosis } \\
\text { results with the data of epidemiological } \\
\text { surveillance on the territory } \\
\text { Making epidemiological diagnosis } \\
\text { and planning the control measures }\end{array}$ & $\begin{array}{l}\text { Detection and real-time } \\
\text { differentiation of enteric virus } \\
\text { RNA (DNA) by PCR } \\
\text { and studying their circulation } \\
\text { Genotyping of samples } \\
\text { positive for enteric viruses } \\
\text { (G[P]-typing of rotaviruses, } \\
\text { sequencing and other } \\
\text { methods) } \\
\text { Phylogenetic analysis } \\
\text { (identification and finding out } \\
\text { evolutionary relationships) } \\
\text { Determining the conditions } \\
\text { of infection occurrence } \\
\text { by comparing the data with } \\
\text { pathogen circulation results } \\
\text { on a specific territory based } \\
\text { on the results } \\
\text { of epidemiological } \\
\text { monitoring AEl in the } \\
\text { hospital }\end{array}$ & $\begin{array}{l}\text { This is carried out: } \\
\text { - as part of production control } \\
\text { or independently } \\
\text { - targets specific departments } \\
\text { or premises and facilities } \\
\text { - in a planned manner and according } \\
\text { to epidemic indications (parameters } \\
\text { depend on the epidemiological situation } \\
\text { in the hospital) } \\
\text { Involves: } \\
\text { - detection and real-time differentiation } \\
\text { of enteric virus RNA (DNA) by PCR } \\
\text { on various environmental objects } \\
\text { The results are the basis: } \\
\text { - for correction of disinfection measures } \\
\text { (selection of virulicidal disinfectant } \\
\text { application, identifying the objects } \\
\text { and facilities for treatment) } \\
\text { - for revealing transmission ways } \\
\text { and factors } \\
\text { - to control the quality of conducted } \\
\text { disinfection measures }\end{array}$ \\
\hline
\end{tabular}

Figure 5. Improved epidemiological surveillance system for acute enteric infections of viral etiology 
7) epidemiological diagnosis and planning the activities to control AEI spread.

The molecular genetic component of microbiological monitoring should include examination of patients and assessment of the environment:

1) examination of patients:

- detection and real-time differentiation of enteric virus RNA (DNA) by PCR and studying their circulation;

- genotyping of samples positive for enteric viruses (G[P]-typing of rotaviruses, sequencing and other methods);

- phylogenetic analysis (identification and finding out evolutionary relationships);

- determining the conditions of infection occurrence by comparing the data with pathogen circulation results on a specific territory (region, district, etc.) based on epidemiological $A E I$ monitoring results in the medical organization.

2) assessment of the environment:

- detection and real-time differentiation of enteric virus RNA (DNA) by PCR method on various environmental objects of the medical organization.

Particular parameters of external environment study in the molecular genetic component of microbiological monitoring should be determined by epidemiological situation in the medical facility. That is, external environment study can be done both in a planned manner and according to epidemic indications, combined with bacteriological research as part of production control or separately, it should target specific departments or premises and facilities of external environment. The scope of activities, study objects and monitoring procedures are selected depending on the epidemiological situation in the medical organization.

The results of the study of environmental contamination with enteric viruses provide the grounds for correction of disinfection measures: selection of virulicidal methods of disinfectant application, identifying the objects and facilities for treatment. In addition, these data are necessary to reveal transmission ways and factors.

The results of PCR studies of the external environment should be used with caution to control the quality of conducted disinfection measures.

It should be noted that studies on enteric virus identification by PCR should be performed by laboratory services of medical companies. Genotyping, phylogenetic analysis, and comparison of the results should be carried out on the basis of reference centers (reference laboratories) for monitoring enteric infections and HAls or other research organizations.

Thus, optimization of epidemiological surveillance for viral enteric infections by improving molecular genetic monitoring can significantly raise effectiveness of detecting environmental contamination and disease as well as successfully differentiate disease cases according to the conditions of occurrence based on genetic characteristics of pathogens and comparison of data on enteric virus circulation on the territory.
Conclusion. In order to improve microbiological monitoring of acute enteric infections, there has been developed a molecular genetic component of viral etiology, which provides not only diagnosis of enteric pathogens by PCR, but also subsequent genotyping as well as phylogenetic analysis to determine genetic characteristics of pathogens.

Study Funding and Conflicts of Interest. This study was not supported by any financial sources and the authors have no conflicts of interest to disclose.

\section{References}

1. Epifanova N.V., Novikova N.A., Efimov E.I., Parfenova O.V., Lukovnikova L.B., Fomina S.G. Moleculargenetic characteristic of astroviruses circulating in Nizhny Novgorod. Zhurnal mikrobiologii, epidemiologii i immunobiologii 2012; 6: 32-36.

2. Epifanova N.V., Lukovnikova L.B., Novikova N.A., Parfenova O.V., Fomina S.G. Epidemic variants of norovirus genotype Gll.4 in Nizhny Novgorod in 2006-2012. Zhurnal mikrobiologii, epidemiologii i immunobiologii 2014; 2: 64-72.

3. Epifanova N.V., Lukovnikova L.B., Golitsina L.N., Fomina S.G., Zverev V.V., Ponomareva N.V., Parfenova O.V., Novikov D.V., Volkova M.A., Novikova N.A. Etiological structure of viral intestinal infections in children in Nizhny Novgorod. Meditsinskiy al'manakh 2010; 2(11): 233-236.

4. Sergeeva A.V., Poslova L.Y., Kovalishena O.V., Blagonravova A.S., Epifanova N.V., Sashina T.A., Morozova O.V., Novikova N.A. Viral etiology acute intestinal infections molecular monitoring in children's hospital. Infektsiya i immunitet 2015; 5(3): 243-252.

5. Kageyama T., Kojima S., Shinohara M., Uchida K., Fukushi S., Hoshino F.B., Takeda N., Katayama K. Broadly reactive and highly sensitive assay for Norwalk-like viruses based on real-time quantitative reverse transcriptionPCR. J Clin Microbiol 2003; 41(4): 1548-1557, https://doi. org/10.1128/jcm.41.4.1548-1557.2003.

6. Noel J.S., Lee T.W., Kurtz J.B., Glass R.I., Monroe S.S. Typing of human astroviruses from clinical isolates by enzyme immunoassay and nucleotide sequencing. J Clin Microbiol 1995; 33(4): 797-801.

7. Zhirakovskaya E.V., Tikunov A.Y., Kurilshchikov A.M., Tikunova N.V., Aksanova R.K., Sokolov S.N., Netesov S.V., Gorbunova M.G. Genetic diversity of group a rotavirus isolates found in Western Siberia in 2007-2011. Molecular Genetics, Microbiology and Virology 2012; 27(4): 174-183, https://doi. org/10.3103/s0891416812040076.

8. Zhirakovskaya E.V., Tikunov A.Yu., Kurilshchikov A.M., Demina A.V., Pokrovskaya I.V., Sheronova O.B., Pozdnyakova L.L., Netesova S.V., Tikunova N.V. The etiological structure of acute enteric infections in adults in Novosibirsk. Infektsionnye bolezni 2013; 11(2): 31-37.

9. Novikova N.A., Epifanova N.V., Fedorova O.F. G[P] genotipirovanie rotavirusov $s$ ispol'zovaniem polimeraznoy tsepnoy reaktsii $[\mathrm{G}[\mathrm{P}]$-genotyping of rotaviruses using the polymerase chain reaction]. Nizhny Novgorod; 2007.

10. Novokshonov A.A., Sokolova N.V., Sakharova A.A., Berezhkova T.V. Clinical efficacy of a new enterosorbent in the complex therapy of acute intestinal infections of viral etiology in children. Lechashchiy vrach 2009; 7: 78-81.

11. Bull R.A., Tu E.T.V., Mclver C.J., Rawlinson W.D., 
White P.A. Emergence of a new norovirus genotype II.4 variant associated with global outbreaks of gastroenteritis. J Clin Microbiol 2006; 44(2): 327-333, https://doi.org/10.1128/ jcm.44.2.327-333.2006.

12. De Grazia S., Platia M.A., Rotolo V., Colomba C., Martella V., Giammanco G.M. Surveillance of human astrovirus circulation in Italy 2002-2005: emergence of lineage 2c strains. Clin Microbiol Infect 2011; 17(1): 97-101, https://doi. org/10.1111/j.1469-0691.2010.03207.x.

13. DiStefano D.J., Kraiouchkine N., Mallette L., Maliga M., Kulnis G., Keller P.M., Clark H.F., Shaw A.R. Novel rotavirus VP7 typing assay using a one-step reverse transcriptase PCR protocol and product sequencing and utility of the assay for epidemiological studies and strain characterization, including serotype subgroup analysis. J Clin Microbiol 2005; 43(12): 5876-5880, https://doi.org/10.1128/jcm.43.12.5876-5880.2005.

14. Yunkerov V.I., Grigor'ev S.G. Matematikostatisticheskaya obrabotka dannykh meditsinskikh issledovaniy
[Mathematical and statistical processing of data for medical research]. Saint Petersburg: VMedA; 2002; 266 p.

15. Glass R.I., Bresee J., Jiang B., Gentsch J., Ando T., Fankhauser R., Noel J., Parashar U., Rosen B., Monroe S.S. Gastroenteritis viruses: an overview. Novartis Found Symp 2001; 238: 5-25, https://doi.org/10.1002/0470846534.ch2.

16. Kambhampati A., Koopmans M., Lopman B.A. Burden of norovirus in healthcare facilities and strategies for outbreak control. J Hosp Infect 2015; 89(4): 296-301, https://doi. org/10.1016/j.jhin.2015.01.011.

17. Mahar J.E., Bok K., Green K.Y., Kirkwood C.D. The importance of intergenic recombination in norovirus Gll.3 evolution. J Virol 2013; 87(7): 3687-3698, https://doi. org/10.1128/jvi.03056-12.

18. Tamura K., Stecher G., Peterson D., Filipski A., Kumar S. MEGA6: molecular evolutionary genetics analysis version 6.0. Mol Biol Evol 2013; 30(12): 2725-2729, https://doi. org/10.1093/molbev/mst197. 